\section{INVESTIGATION ON THE BARRIERS OF CRUMB RUBBER USAGE FOR ROADS CONSTRUCTION: CASE STUDY AT SABAH}

\author{
Lillian Gungata*, Melbourne Dinola Dagula, Elsa Eka Putrib
}

aCivil Engineering Programme, Faculty of Engineering, Universiti Malaysia Sabah, Malaysia bDepartment of Civil Engineering, Faculty of Engineering, University of Andalas, Padang, Indonesia
Article history

Received

22 June 2021

Received in revised form

26 September 2021

Accepted

7 November 2021

Published Online

21 February 2022

*Corresponding author lillian@ums.edu.my

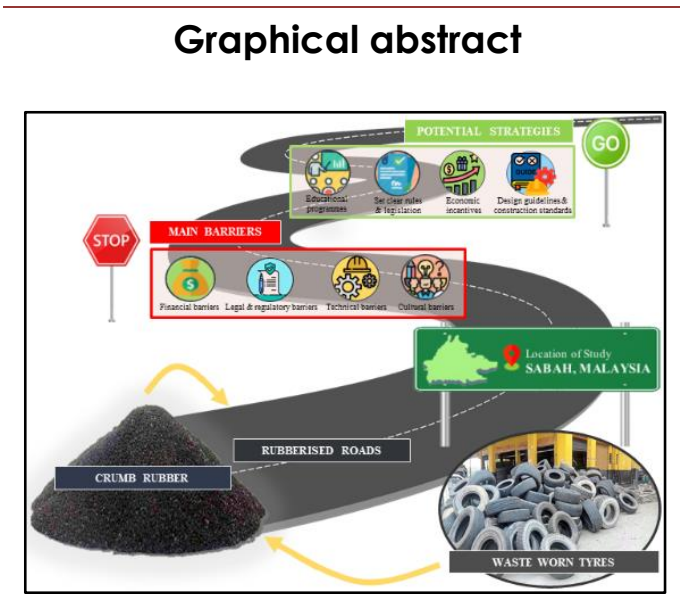

\begin{abstract}
The usage of crumb rubber in road construction has been widely acknowledged and extensively implemented globally and even locally in Malaysia due to the substantial benefits and versatility of this material contribution in road works. Even though the used of crumb rubber material in road works has been reported since the 1950s, in Malaysia, the implementation of rubberised roads technology concept have been limited and emphasised only in Peninsular Malaysia. In contrast, there have been no recorded trials or construction inroads applying this technology in Sabah. Therefore, there is a necessity to investigate the awareness, advantages, barriers, strategies, and personal opinion regarding crumb rubber usage in the road's construction of Sabah. Questionnaire surveys and structured interviews from stakeholders of the construction industries within Sabah were conducted. The quantitative data collected was tested by descriptive statistics frequencies analysis respective to each section. Further assessment on Cronbach's Alpha test, mean value comparison, relative important index, chi-square test and regression analysis were performed to interested sections. Findings showed that the main advantages and barrier were environmentally friendly factor and financial barriers. Hence respondents propose that guidelines and construction standards as a guidance for the local road agency to be available.
\end{abstract}

Keywords: Crumb rubber, roads construction, barriers, sustainable, quantitative

\begin{abstract}
Abstrak
Penggunaan getah remah dalam pembinaan jalan raya telah diakui secara meluas dan dilaksanakan secara meluas di peringkat global dan tempatan di Malaysia disebabkan banyak faedah dan fleksibiliti sumbangan bahan ini dalam kerja jalan. Walaupun penggunaan bahan getah remah dalam jalan raya telah dilaporkan sejak tahun 1950-an, di Malaysia, pelaksanaan konsep teknologi jalan getah terbatas dan ditekankan hanya di Semenanjung Malaysia. Sebaliknya, tidak ada percubaan direkodkan atau pembinaan kalan yang menggunakan teknologi ini di Sabah. Oleh itu, terdapar keperluan untuk menyelidiki tahap kesedaran, kelebihan, halangan, strategi, dan pendapat peribadi mengenai penggunaan getah remah dalam pembinaan jalan raya di Sabah. Tinjauan soal selidik dan wawancara berstruktur dari pihak berkepentingan industri pembinaan di Sabah telah dilakukan. Data kuantitatif yang dikumpulkan diuji dengan analisis frekuensi statistik deskriptif berkenaan setiap bahagian. Penilaian lebih lanjut mengenai ujian Cronbach's Alpha, perbandingan nilai min, indeks penting relatif, ujian chi-square dan analisis regresi dilakukan ke bahagian yang
\end{abstract}


berkenaan. Hasil kajian menunjukkan bahawa kelebihan dan halangan utama adalah faktor mesra persekitaran dan halangan kewangan. Oleh itu responden mencadangkan agar garis panduan dan piawaian pembinaan sebagai panduan untuk agensi jalan raya tempatan perlu disediakan.

Kata kunci: Getah remah, pembinaan jalan, halangan, mampan, kuantitatif

(C) 2022 Penerbit UTM Press. All rights reserved

\subsection{INTRODUCTION}

Most rubber tyres of road vehicles are susceptible to be worn-out and the necessities of tyre replacements are required consistently. With the massive demand of rubber tyres production, including about 1.4 billion rubber tyres manufacture annually worldwide [1], this eventually increases the disposal of worn and end-oflife rubber tyres, which have currently become a global environmental problem [2], [3].

One of the beneficial approaches to utilising waste rubber tyres is using the crumb rubber material extracted from the waste tyres to incorporate in road construction [4], [5]. Crumb rubber is a tyre-derived material produced by shredding and grinding scrap or waste tyres into fine particles [4]. There are two main methods in crumb rubber production from waste rubber tyres: ambient granulating and cryogenic grinding. The similarities of both these processes substantially minimise the size of the tyre and segregate the steel belting and fibre from the rubber compound [6]. This material is analysed to have numerous possible potential uses in the engineering construction fields besides for road development due to its significant benefits to engineering application and environmental protection [4], [5]. Generally, the most apparent advantages of implementing crumb rubber usage for road construction increase the performance of road construction feasible alternatives in terms of engineering applications, decrease the environmental impacts, and maximise the conservation of natural resources. The benefits of implementing crumb rubber usage for the construction of roads are becoming more extensively practised and renowned, and the incorporation of rubber tyres into asphalt is possible to escalate [1].

Research findings on the usage of crumb rubber in roads construction show various significant enhancement in engineering properties on the road characteristics. It is found that most engineering properties on-road performances increase, as the crumb rubber implemented in rubberised asphalt mixture reduces in fineness [7], whereby the crumb rubber concretation and size have a considerable effect on the properties of the approximation asphalt moodified binder [8]. Past experimental tests for road engineering properties conducted on crumb rubber roads results in most postive outcomes. As such, the penetration test value of bitumen mixture decreases as the conncentration of crumb rubber used in the mixture increased, individually up to $20 \%$ of the total weight of the bitumen [9]. This factor will influence better strength to the structure of the road to resist permanent deformation and less temperature susceptible [10]. The reading in softening point test increases with the increment of crumb rubber content [9]. By which previous study results in the average reading for control bitumen with approximatley $43^{\circ} \mathrm{C}$ while the mean value for crumb rubber-bitumen mixture for $8 \%$ and $14 \%$ are $50^{\circ} \mathrm{C}$ and $55^{\circ} \mathrm{C}$ respectively, this indicates benefits in less vulnerable to temperature alteration and hence preferably to hot climate regions [10]. Recent studies highlighed some findings on Marshall Stability test, that the value increases as the content of fine crumb rubber increses [11], [12], [13] whereas, minimal addition of crumb rubber decreases the stability value of the mixture [14]. Higher value of Marshall Stability test indicates that the crumb rubber asphaltic mixture is resistance to rutting and permanent deformation due to heavy traffic loads [11].

Incorporate crumb rubber from waste or end-oflife tyres for road construction usage has received much attention in several countries in Asia, Europe, and Africa these recent years [9]. Crumb rubber, a tyre-derived material, has become the world's common usage for road construction as an additive to a bituminous binder since the 1960s [15]. It depicts that the knowledge of applying crumb rubber in road construction that is established decades ago is still significant and comprehensively used in today's construction technology with several alterations and improvements. In Malaysia, trial usage of rubberised bitumen was initiated in the 1950s with a 100 yards of road construction between Kuala Krai and Kota Bharu with incorporating $5 \%$ of crumb rubber [16]. Then followed by several trials done at the states of Perlis, Kedah, Negeri Sembilan, Melaka and Johor, nevertheless, there were no recorded findings attained from these trials [17]. Thus, numerous research have been conducted to identify approaches to enhacne the technology for developing crumb rubber modified asphalt, as such Jabatan Kerja Raya (JKR) Malaysia and Institut Penyelidikan Getah Malaysia have been joint venture to ascertain the capability of applying crumb rubber in roads construction [18]. 
From several trials, today, Malaysia comprises networks of crumb rubber-based road construction with better technology improvement. However, the field trial construction of crumb rubber-based roads focuses on Peninsular Malaysia. In contrast, in Sabah, roads with the crumb rubber technology have never been noticeably implemented. Thus there is a need to investigate the barriers of crumb rubber usage for road construction, particularly in Sabah. Mainly to identify the challenges and ways to solve these constraints of crumb rubber usage in road construction.

\subsection{METHODOLOGY}

Quantitative research method was selected since the research information on samples' investigated variables was attained through statistical data collection [19]. The raw data collections were purely based on the conduct of closed-ended questionnaires and structured interviews. The preferable type of respondents centred on the key stakeholders and representatives mainly involved with road constructions and maintenances. The selection of respondents was open to both government and private consultancy and contractor sectors. A minimum of 10 respondents was required from seven (7) divisional zones of Jabatan Kerja Raya (JKR) Sabah. According to Whitehead et. al. (2016) the target sample size of 70 based on the rules of thumb for the pilot study is acceptable as to minimize the inaccuracy around the approximate of the standard deviation [20]. In addition, three interviews with engineers that has experience in road related job was conducted. These data were analysed via computerised based software of Microsoft Excel and SPSS, namely by testing descriptive statistics frequencies analysis, Cronbach's Alpha, mean values comparison, relative important index (RII), and chisquare test. The flow chart of the methodology for this study is presented in Figure 1.

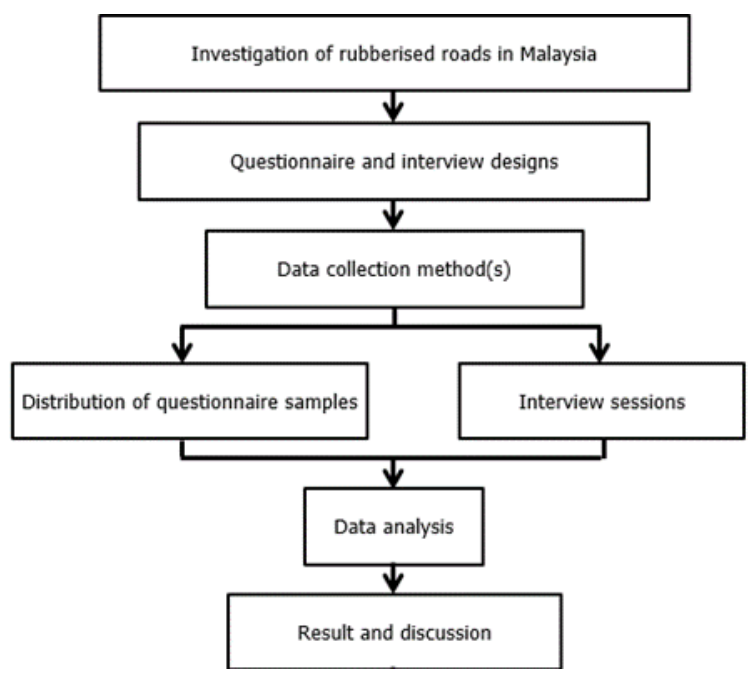

Figure 1 Flow chart of the methodology

\subsection{RESULTS AND DISCUSSION}

A total of 103 respondents have answered as collected in both questionnaire surveys and structured interviews. Higher sample size has the possibility to enhance the nearest accuracy and reliability of the research since larger samples produce a better approximation of the population [21].

The profile of respondents from the whole seven divisional zones of Sabah was analysed concurrently. The profiles of respondents were interpreted with descriptive statistics frequencies analysis by eight questions related to the personal and background scope in the form of frequency counts and percentages for comparison purposes. Table 1 depicts the 103 stakeholders' demographic data that participated in this study.

Table 1 Demographic data of respondents

\begin{tabular}{lll}
\hline Categories & Frequency & Percentages \\
\hline Age & & \\
\hline Below 30 & 29 & 28.2 \\
$30-40$ & 48 & 46.6 \\
$40-50$ & 19 & 18.4 \\
$50-60$ & 7 & 6.8 \\
\hline Academic Qualification & & \\
\hline PhD & 1 & 1.0 \\
Masters Degree & 18 & 17.5 \\
First Degree & 48 & 46.6 \\
Others & 36 & 35.0 \\
\hline Working Experience in Construction Industries \\
\hline Less than five years & 24 & 23.3 \\
Between 5 to 10 years & 10 & 9.7 \\
Between 10 to 15 years & 43 & 41.7 \\
Between 15 to 20 years & 10 & 9.7 \\
More than 20 years & 16 & 15.5 \\
\hline Working Experience in Road Construction & \\
\hline Less than five years & 39 & 37.9 \\
Between 5 to 10 years & 9 & 8.7 \\
Between 10 to 15 years & 42 & 40.8 \\
Between 15 to 20 years & 7 & 6.8 \\
More than 20 years & 6 & 5.8 \\
\hline Type of Organisation & & \\
\hline Government & 56 & 54.4 \\
Consultants & 12 & 11.7 \\
Contractor & 35 & 34.0 \\
\hline Status of Position & & \\
\hline Engineer & 53 & 31.5 \\
Assistant Engineer & 32 & 10.7 \\
Technician/Supervisor & 11 & 3.9 \\
Others & 7 & \\
\hline Scope of Work & & \\
\hline Road Construction & 37 & \\
Structure Construction & 37 & \\
Others & 3 & \\
\hline & & \\
\hline
\end{tabular}

The respondents were assessed on the awareness, knowledge, and understanding personally and as in an organization regarding road construction and crumb rubber.

Figure 2 is a combination of three graphs primarily on the respondents' knowledge and understanding, effort towards developing knowledge and willingness 
to adapt and change on the usage of crumb rubber in construction, specifically roadworks.

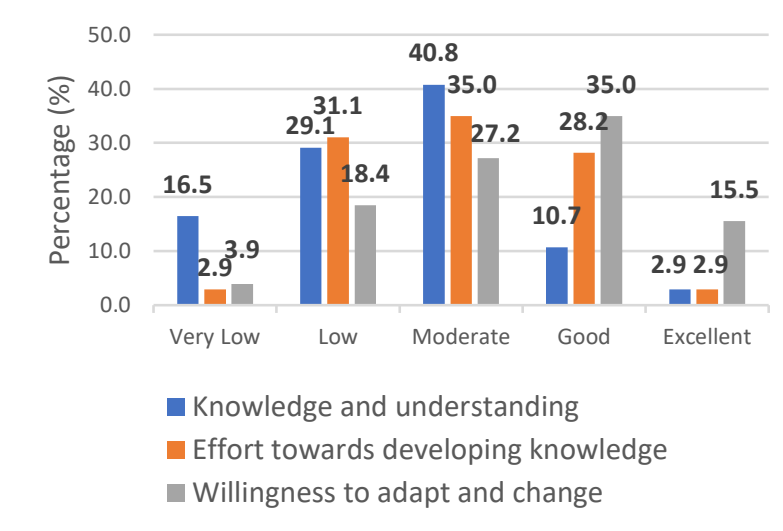

Figure 2 Respondents' knowledge and understanding, effort towards developing knowledge and willingness to adapt and change

From Figure 2 most of the respondents (40.8\%) acknowledged a moderate rating on the knowledge and understanding of crumb rubber usage. Similarly, $29.1 \%$ and $16.5 \%$ respondents answered low and very low, respectively, whereas only $10.7 \%$ and $2.9 \%$ respondents considered as good and excellent. Investigated by previous studies conducted in respective countries of Kuwait and Malaysia, similar trends were found in which most respondents were prone to declare in having within the moderate scale rating knowledge on sustainability [22], [23].

Effort of the respondents toward developing knowledge on the concept of using sustainable material (crumb rubber) in construction, as shown in Figure 2, rating of low to moderate were the majority responses gained from the local respondents. This can be justified as stated by the previous researcher, whereby the effort of response and progress rate in Malaysia is still unsatisfactory and hence should be increased to meet worldwide standards [24], this is probably due to some construction industries do not put enough effort and are only content with satisfying the minimum requirement and law [25].

Figure 2 also depicts the willingness of the respondents to take action by integrating any changes needed to apply crumb rubber in construction as in road development. Based on the findings, the positive reactions in respect to the question were slightly higher than the negative ratings. However, opposite findings were reported based on local research in Malaysia, as most construction projects are not willing to change from the traditional way of construction [26]. Due to the comfortability of the construction industry's norm and system, the profit margin was guaranteed by the conventional construction approach [24], [25]. In Sabah, this can be justified as to the relevant assessment on the advantages of sustainability which influences the willingness of the respondents to adopt the sustainable approach [27].

Figure 3 shows the level of awareness of the respondents' company towards the usage of crumb rubber as material usage in road construction. Previous research on sustainable construction stated that extensive and well-developed companies employed with numbers of professionals have a higher potential to be aware and knowledgeable on sustainable development than medium and smallsized companies [25]. In Sabah, the number of medium and small-sized construction companies surpasses the few numbers well-developed companies. Hence the technology and growth in the construction of Sabah compared to Peninsular Malaysia are still behind.

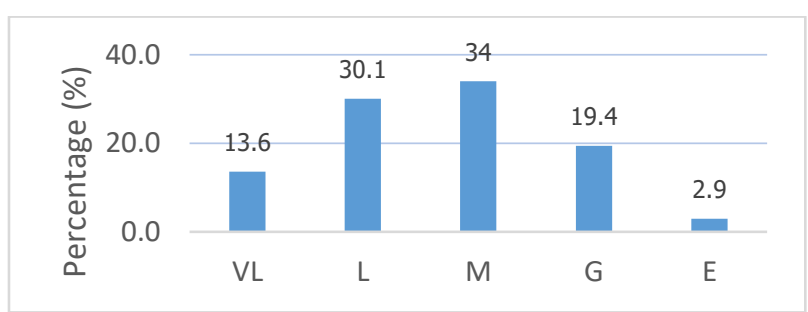

Note: $\mathrm{VL}=$ Very low, $\mathrm{L}=\mathrm{L}$ Low, $\mathrm{M}=$ Moderate, $\mathrm{G}=\mathrm{Good}$ and $\mathrm{E}=$ Excellent

Figure 3 Respondents' company level of awareness

Figure 4 shows the respondents' perception on the role of the government in promoting sustainable construction practices. Comparable results were found with a past study, as the vast majority of the respondents voted strongly agree (SA) and agree (A) on the same context of the statement with less voted on neutral (N). None on disagree (D) and strongly disagree (SD). This is due mainly to the respondents' popular belief that they strongly perceive the government as the critical element in encouraging sustainable development in the construction industry [28].

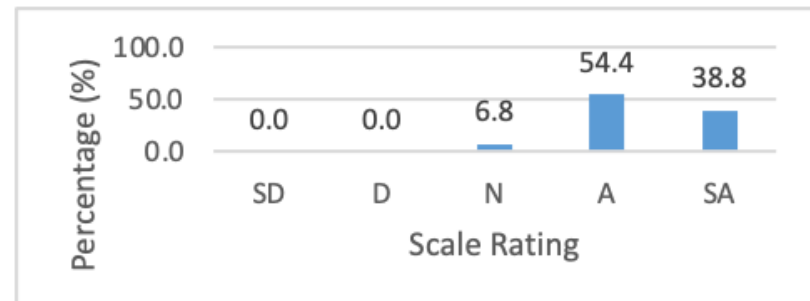

Note: $\mathrm{SD}=$ Strongly disagree, $\mathrm{D}=$ Disagree $, \mathrm{N}=\mathrm{Neutral}, \mathrm{A}=$ Agree and $S A=$ Strongly agree

Figure 4 Perception of the role of the government in promoting sustainable construction practices

The respondents were then surveyed on the types of benefits of implementing crumb rubber in road construction. The internal consistency measured yielded a Cronbach's Alpha value of $0.87(a>0.70)$. Thus, the reliability of the data collected was acceptable. The results are presented in Table 2. 
Table 2 Analysis of advantages

\begin{tabular}{|c|c|c|c|c|c|c|c|c|}
\hline \multirow{2}{*}{$\begin{array}{c}\text { Types of } \\
\text { Advantages }\end{array}$} & \multicolumn{5}{|c|}{ Scale Rating (\%) } & \multirow[b]{2}{*}{$\begin{array}{l}\text { Mean } \\
\text { Value }\end{array}$} & \multirow[b]{2}{*}{ RII } & \multirow[b]{2}{*}{$\begin{array}{l}\text { Ran- } \\
\text { king }\end{array}$} \\
\hline & $\begin{array}{l}S \\
D\end{array}$ & D & $\mathbf{N}$ & A & SA & & & \\
\hline $\begin{array}{l}\text { Reduce natural } \\
\text { resource } \\
\text { consumption }\end{array}$ & 0 & 2.9 & 40.8 & 35 & 21.4 & 3.75 & 0.75 & 3 \\
\hline $\begin{array}{l}\text { Improve road } \\
\text { performance }\end{array}$ & 0 & 2.9 & 44.7 & 31.1 & 21.4 & 3.71 & 0.74 & 4 \\
\hline $\begin{array}{l}\text { Environmentally } \\
\text { friendly }\end{array}$ & 0 & 1 & 35 & 28.2 & 35.9 & 3.99 & 0.80 & 1 \\
\hline $\begin{array}{c}\text { Economical } \\
\text { beneficial }\end{array}$ & 0 & 2.9 & 39.8 & 32 & 25.2 & 3.80 & 0.76 & 2 \\
\hline
\end{tabular}

Based on Table 2, the most known benefits and ranked first by the evaluation given was 'environmentally friendly, followed by 'economical beneficial,' then 'reduce natural resource consumption,' lastly 'improve road performance.' However, besides resolving environmental concerns, better durability, improve adhesion between aggregate and binder mixture, cracking resistance, reflective cracking, and enhanced performances in extreme temperature conditions and under heavy traffic loadings are recorded as the preferences benefits of using crumb rubber in roadworks [29] [30]. Thus, it was shown that there were various positive findings of rubberised roads in enhancing road performances. However, the awareness of these benefits is still indecisively low in Sabah's construction industry, as presented from the study findings. The majority of the respondents were only inclined to assume that the usage of crumb rubber in road construction is the preference for environmental purposes.

The respondent was also surveyed to identify the barriers of crumb rubber usage for road construction in Sabah. The value of consistency as tested was 0.79, which complies with the coefficient of dependability. The results are presented in Table 3.

Table 3 Analysis of barriers

\begin{tabular}{cccc}
\hline $\begin{array}{c}\text { Main Categories of } \\
\text { Barriers }\end{array}$ & $\begin{array}{c}\text { Average Mean } \\
\text { Value }\end{array}$ & Average RII & Ranking \\
\hline Financial barriers & 3.82 & 0.76 & 1 \\
Technical barriers & 3.55 & 0.71 & 3 \\
Legal and regulatory & 3.63 & 0.73 & 2 \\
barriers & 3.40 & 0.68 & 4 \\
Cultural barriers & &
\end{tabular}

Based on the analysis, it was observed that the main barriers in regards to this study were primarily due to "financial barriers" with the highest average mean value and Rll, followed by "legal and regulatory barriers," than "technical barriers" lastly "cultural barriers." The comparable situation was discovered in previous studies, by which most often the construction industry stakeholders perceived "financial barriers" as the primary problem that prevents sustainable development usage [31], [32]. This is probably due to the unease and indecisiveness of implementing green construction due to the high initial cost and future unforeseen financial issues [26].

An in-depth measure of the chi-square test and regression analysis were performed to analyse the relationship between the respondents' demographic details with the four identified significant barriers. The analysis conducted at 0.05 significant level based on the following hyphothesis:

$\mathrm{H}_{0}$ : There is no relationship between demographic of repsondent and barriers.

$\mathrm{H}_{\mathrm{a}}$ : There is a relationship between demographic of repsondent and barriers.

Chi - square test and regression were performed and the result as tabulated in Table 4 and Table 5.

Table 4 Chi-square test

\begin{tabular}{ccccc}
\hline $\begin{array}{c}\text { Demographic Details } \\
\text { of Respondent }\end{array}$ & $\begin{array}{c}\text { Financial } \\
\text { Barriers }\end{array}$ & $\begin{array}{c}\text { Technical } \\
\text { Barriers }\end{array}$ & $\begin{array}{c}\text { Legal and } \\
\text { Regulatory } \\
\text { Barriers }\end{array}$ & $\begin{array}{c}\text { Cultural } \\
\text { Barriers }\end{array}$ \\
\hline Age & 0.603 & 0.378 & 0.102 & 0.428 \\
$\begin{array}{c}\text { Academic } \\
\text { Qualification }\end{array}$ & 0.232 & 0.025 & 0.808 & 0.213 \\
$\begin{array}{c}\text { Working Experience in } \\
\text { Construction Industries } \\
\text { Working Experience in } \\
\text { Roads Construction } \\
\text { Sector }\end{array}$ & 0.157 & 0.763 & 0.001 & 0.122 \\
$\begin{array}{c}\text { Organization Type } \\
\begin{array}{c}\text { Working Status of } \\
\text { Position }\end{array}\end{array}$ & 0.033 & 0.400 & 0.000 & 0.126 \\
\hline $\begin{array}{c}\text { Current Scope of Work } \\
\text { non }\end{array}$ & 0.707 & 0.634 & 0.532 & 0.062 \\
\hline
\end{tabular}

Table 5 Regression analysis

\begin{tabular}{ccccc}
\hline $\begin{array}{c}\text { Demographic Details } \\
\text { of Respondent }\end{array}$ & $\begin{array}{c}\text { Financial } \\
\text { Barriers }\end{array}$ & $\begin{array}{c}\text { Technical } \\
\text { Barriers }\end{array}$ & $\begin{array}{c}\text { Legal and } \\
\text { Regulatory } \\
\text { Barriers }\end{array}$ & $\begin{array}{c}\text { Cultural } \\
\text { Barriers }\end{array}$ \\
\hline Age & 0.613 & 0.469 & 0.042 & 0.739 \\
$\begin{array}{c}\text { Academic } \\
\text { Qualification }\end{array}$ & 0.054 & 0.012 & 0.885 & 0.200 \\
$\begin{array}{c}\text { Working Experience in } \\
\text { Construction Industries } \\
\text { Working Experience in } \\
\text { Roads Construction } \\
\text { Sector }\end{array}$ & 0.068 & 0.522 & 0.060 & 0.400 \\
$\begin{array}{c}\text { Organization Type } \\
\begin{array}{c}\text { Working Status of } \\
\text { Position }\end{array}\end{array}$ & 0.174 & 0.330 & 0.000 & 0.835 \\
$\begin{array}{c}\text { Current Scope of Work } \\
\text { (1) }\end{array}$ & 0.233 & 0.000 & 0.008 & 0.784 \\
\hline
\end{tabular}

These results as shown in Table 4 and Table 5 indicates that the demographic factors and the barriers which had significant values of $p$-value $<0.05$ tend to have a corresponding correlation. Based on Table 4 and Table 5, several different significant $p$ values were yielded from both of the respective 
statistical examinations. The age factor showed no significant relation to neither of the barriers tested in chi-square values produced higher than the significant level, a p-value of 0.05. However, as tested in regression analysis there is a significant relation in between the age factor with the "legal and regulatory barriers". As for the academic qualification, the only significant value obtained from both the correlation analysis of chi-square and regression analysis was "technical barriers." Regarding working experience in the construction industries, the only significant correlation was "legal and regulatory barriers" as obtained from chi-square test, nevertheless significant relationship was not obtained by regression analysis for this particular relationship. The working experience in road construction sectors shows that the significant value for "legal and regulatory barriers" have substantial importance tested from both chisquare test and regression analysis, moreover chisquare test also obtained significant value for "financial barriers". In terms of organisation type, the "financial barriers" developed a significant value tested with chi-square test but none in regression analysis. As for the position's working status, both tests produced a significant value for "technical barriers", and addition on "legal and regulatory barriers" was also gained from this factor based on regression analysis. The current scope of work indicated that the only "legal and regulatory barriers" with significant value as examined by both tests.

To determine possible modifications in eliminating or minimising the crumb rubber application barriers for road construction in Sabah, the respondents were required to respond. The obtained Cronbach's Alpha, a value for this was 0.94, which shows high internal consistency. The results are shown in Table 6.

Table 6 Analysis of strategies

\begin{tabular}{|c|c|c|c|c|c|c|c|c|}
\hline \multirow{2}{*}{$\begin{array}{l}\text { Types of } \\
\text { Potential } \\
\text { Strategies }\end{array}$} & \multicolumn{5}{|c|}{ Scale Rating (\%) } & \multirow{2}{*}{$\begin{array}{l}\text { Mean } \\
\text { Value }\end{array}$} & \multirow{2}{*}{ RII } & \multirow{2}{*}{ Ranking } \\
\hline & $\begin{array}{l}\text { S } \\
\text { D }\end{array}$ & D & $\mathbf{N}$ & A & SA & & & \\
\hline $\begin{array}{l}\text { Educational } \\
\text { programmes }\end{array}$ & 0 & 0 & 8.7) & 28 & 27.2 & 4.18 & 0.84 & 4 \\
\hline $\begin{array}{l}\text { Set clear } \\
\text { rules and } \\
\text { legislation }\end{array}$ & 0 & 0 & 4.9) & 66. & 29.1 & 4.24 & 0.85 & 3 \\
\hline $\begin{array}{l}\text { Design } \\
\text { guidelines } \\
\text { and } \\
\text { construction } \\
\text { standards }\end{array}$ & 0 & 0 & 4.9 & 61.2 & 34 & 4.29 & 0.86 & 1 \\
\hline $\begin{array}{l}\text { Economic } \\
\text { incentives }\end{array}$ & 0 & 0 & 5.8 & 60.2 & 34 & 4.28 & 0.86 & 2 \\
\hline
\end{tabular}

Based on Table 6, the data portrayed a encouraging response from the respondents in embracing the sustainable construction of using crumb rubber for roadworks. Since to emerge new practices in construction, strategies were needed to accelerate and reassure efforts towards the implementation [33], [34] "design guidelines and construction standards" was ranked first as the potential strategy in overcoming the barriers of crumb rubber application for roadworks in Sabah, followed by "economic incentives," then "set rules and legislation" and last "educational programs." However, Malaysia has been implemented crumb rubber in various road construction, mainly in the Peninsular states during the past years, and Standard Specification for Road Works (Section 4: Flexible Pavement) Addendum Specification For Rubber Modified Asphalt (Section 4.17: Crumb Rubber Modified Asphalt) has also been introduced. Hence, strategy by "design guidelines and construction standards" in terms of crumb rubber for road construction has been implemented but has not successfully impacted the construction industry in Sabah.

\subsection{CONCLUSION}

Based on the stakeholders in Sabah, most of the responses were rated moderate towards the level of knowledge and understanding on the usage of crumb rubber in construction, specifically roadworks. As for the effort of developing knowledge on the concept in using sustainable material in construction, the highest rated were low to moderate. Nevertheless, for the willingness of the respondents to adapt and change by integrating any sustainable material (crumb rubber) in construction was rated positively with good rating as the highest. Although, the level of awareness of the respondents' respective companies towards the usage of crumb rubber in roads construction were mostly rated low to moderate.

The most obstructive factor amid on the four major barriers (financial barriers, technical barriers, legal and regulatory barriers and cultural barriers) in the application of crumb rubber for road construction in Sabah, was "financial barriers" based on the responses of stakeholders in Sabah. Followed by "legal and regulatory barriers", then "technical barriers" lastly "cultural barriers".

In order to overcome these barriers, most of the stakeholders in Sabah highly desirable strategy was by "designing guidelines and construction standards" on the implementation of crumb rubber usage in roads construction. Whereby this result showed that the construction stakeholders of Sabah were not aware of the latest standard and specification on crumb rubber for roads construction development as introduced by the JKR Malaysia. This is most probably due to the lack of awareness towards crumb rubber or sustainable resources as a construction material which corresponds to the result as depicted in Figure 3.

\section{Acknowledgement}

The authors fully acknowledged Universiti Malaysia Sabah and all respondents which makes this important research viable. 


\section{References}

[1] Lo Presti, D. 2013. Recycled Tyre Rubber Modified Bitumens for Road Asphalt Mixtures: A Literature Review. Construction and Building Materials. 49: 863-881. DOI: 10.1016/j.conbuildmat.2013.09.007.

[2] Bano, S. and Ahmad, S. A. 2018. Application of Waste Tyre in Highway Pavement: A Literature Review. Journal of Civil Engineering and Environmental Technology. 5(8): 556-562.

[3] Nuzaimah, M., Sapuan, S. M., Nadlene, R., \& Jawaid, M. 2018. Recycling of Waste Rubber as Fillers: A Review. IOP Conference Series: Materials Science and Engineering. 368(1): 1-9. DOI: 10.1088/1757-899X/368/1/012016.

[4] Rosli, M. H., Aziz, M. A., Adnan, A. M., Hassan, N. A., Jaya, R. P., \& Hong, Y. L. 2015. Performance of Modified Asphalt Binder with Tire Rubber Powder. Jurnal Teknologi (Sciences \& Engineering). 73(4): 55-60. DOI: 10.11113/jt.v73.4288.

[5] Cetin, A. 2013. Effects of Crumb Rubber Size and Concentration on Performance of Porous Asphalt Mixtures. International Journal of Polymer Science. 2013: 1-10. DOI: 10.1155/2013/789612.

[6] Hassan, N. A., Airey, G. D., Jaya, R. P., Mashros, N., \& Aziz, M. A. 2014. A Review of Crumb Rubber Modification in Dry Mixed Rubberised Asphalt Mixtures. Jurnal Teknologi (Sciences \& Engineenring). 70(4): 127-134.

DOI: $10.11113 /$ jt.v70.3501.

[7] Hamad, G. S., Jaya, R. P., Hassan, N. A., Aziz, M. M. A., \& Yusak, M. I. M. 2014. Influences of Crumb Rubber Sizes on Hot Mix Asphalt Mixtures. Jurnal Teknologi. 71 (3): 63-68. DOI: 10.11113/jt.v71.3760.

[8] Bandini, P. 2011. Rubberized Asphalt Concrete Pavements in New Mexico: Market Feasibility and Perfomance Assesment. New Mexico: Prepared for the New Mexico Environmental Department and South Central Solid Waste Authority. Department of Civil Engineering.

[9] Altieb, Z. A., Aziz, M. M. A., Kassim, K. A. \& Jibrin, H. B. 2016. A Short Review on Using Crumb Rubber as Modification of Bitumen Binder. Jurnal Teknologi (Sciences \& Engineering), 78(7-3): 29-36. DOI: 10.1111 13/jt.v78.9479.

[10] Deshmukh, N. H., and Kshirsagar, P. D. Y. 2017. Utilization of Rubber Waste in Construction of Flexible Pavement. International Journal of Advance Research and Development. 2(7): 70-77.

[1 1] Al Qudah, A., Rahim, M. A., Ghazaly, Z. M., Mashaan, N. S., Koting, S., Napiah, M., Omar, W. M. S. W., \& Issa, Y. 2018. Effect of Aged Crumb Rubber Bitumen on Performance Dense Graded Mix in Malaysia. International Journal of Civil Engineering and Technology. 9(4): 1356-1369.

[12] Wulandari, P. S. and Tjandra, D. 2017. Use of Crumb Rubber As an Additive in Asphalt Concrete Mixture. Procedia Engineering. 171: 1384-1389. DOI: 10.1016/j.proeng.2017.01.451.

[13] Suganpriya, V., Omprakash, S., \& Chandralega, V. 2016. Study of Behaviour of Bitumen Modified with Crumb Rubber. International Journal of Engineering Research \& Technology. 5(5): 192-197.

[14] Tefera, B. Y., Tadele, K. \& Geremew, A. 2018. Evaluation of the Effect of Rubber Modified Bitumen on Asphalt Performance. American Journal of Civil Engineering. 6(3): 87-92. DOI: 10.11648/j.ajce.20180603.11.

[15] Wu, J. P., Herrington, P. R., and Neaylon, K. 2015. Removing Barriers to the Use of Crumb Rubber in Roads. 2015, New Zealand, Opus Research.

[16] Harun, M. H., and Razali, R. 2013. Do We Need Crumb Rubber Asphalt? Jurnal Jabatan Kerja Raya Malaysia. 1: 5870.

[17] Othman, Z., Hainin, M. R., Warid, M. N M., Idham, M. K., \& Kamarudin, S. N. N. 2018. Cup Lump Modified Asphalt mixture Along Jalan Kuala Lumpur - Kuatan, Dareah Temeroh, Pahang. MATEC Web of Conferences 250, 02007.
DOI: $10.1051 /$ matecconf/201825002007.

[18] Milad, A., Ahmeda, A., G., F., Taib, A. M., Rahmad, S., Solla M., Yusoff, N. I. M. 2020. A Review of the Feasibility of Using Crumb Rubber Derived From End-of-Life Tire as Asphalt Binder Modifier. Journal of Rubber Research. DOI: 10.1007/s42464-020-00050-y.

[19] Abdullah, S. H., and Raman, S. 2001. Quantitative and Qualitative Research Methods: Some Strengths and Weakness. Jurnal Pendidik Dan Pendidikan. 17: 120-134.

[20] Whitehead, A. L., Julious, S. A., Cooper, C. L., \& Campbell, M. J. 2016. Estimating the Sample Size for a Pilot Randomized Trial to Minimize the Overall Trial Sample Size for the External Pilot and Main Trial for a Continuous Outcome Variable. Statical Mehtods in Medical Research. 25(3): 1057-1073.

[21] Kelley, K., Clark, B., Brown, V. \& Sitzia, J. 2003. Methodology Matters: Good Pratice in the Conduct and Reporting of Survey Research. International Journal for Quality in Health Care. 15(3): 261-266. DOI: 10.1093/intqhc/mzg031.

[22] AlSanad, S. 2015. Awareness, Drivers, Actions and Barriers of Sustainable Construction in Kuwait. Procedia Engineering. 1 18: 969-983. DOI: 10.1016/j.proeng.2015.08.538.

[23] Abidin, N. Z. 2009. Sustainable Construction in Malaysia Developers' Awareness. Proceedings of World Academy of Science, Engineering and Technology. 41: 807-814.

[24] Bahaudin, A. Y., Elias, E. M., Nawi, M. N. M., Zainuddin, N. \& Nadarajan, S. 2017. Construction Sustainability and Awareness amongst Contractor in the Northern Region of Malaysia. International Journal of Supply Chain Management. 6(2): 259-264.

[25] Abidin, N. Z. 2010. Investigation the Awareness and Application of Sustainable Construction Concept by Malaysian Developers. Habitat International. 34: 421-426. DOI: 10.1016/j.habitatint.2009.11.011.

[26] Ha, C. Y., Ismail, R., and Khoo, T. J. 2020. The Barriers of Implementing Green Building in Penang Construction Industry. Progress in Energy and Environment. 12: 1-10.

[27] Oke, A., Aigbavboa, C. and Looyen, D. 2016. Influences of Sustainable Construction Pratices in South Africa. Proceeding of International Conference on Sustainable Built Environment. 525-528.

[28] Samari, M., Ghodrati, N., and Shafiei, M. W. M. 2012. Implementation of Sustainable Development in Construction Industry in Penang Island. Awam International Conference on Civil Engineering. 670-677.

[29] Hanumantharao, C., Anil, P. T., Durga, P. K., Naveen, K. N., Shantha, K. R. G., \& Hemanth, V. M. 2019. Crumb Rubber Modified Bitumen and Quarry Dust in Flexible Pavements. International Journal of Recent Technology and Engineering. 8(1): 2868-2873.

[30] Shubham, B., Anil, K. M., and Purnima, B. 2017. Evaluation of Modified Bituminous Concrete Mix Developed using Rubber and Plastic Waste Materials. International Journal of Sustainable Built Environment. 6(2): 442-448. DOI: 10.1016/j.jijsbe.2017.07.009.

[31] Durdyev, S., Zavadskas, E. K., Thumell, D., Banaitis, A. \& Intiyar, A. 2018. Sustainable Construction Industry in Cambodia: Awareness, Drivers and Barriers. Sustainability. 10(2): 392. DOI: 10.3390/sul0020392.

[32] Nusa, F. N. M., Endut, I. R., and Ishak, S. Z. 2015. Challenges of Green Highway Concept towards Implementation of Green Highway. Applied Mechanics and Material. 747: 36. DOI: 10.4028/www.scientific.net/AMM.747.3.

[33] Shi, Q., Zuo, J., Huang, R., Huang, J., \& Pullen, S. 2013. Identifying the Critical Factors for Green Construction - An Empirical Study in China. Habitat International. 40: 1-8. DOI: 10.1016/j.habitatint.2013.01.003.

[34] Liu, Y. J., Low, S. P. and He, X. 2012. Green Practices in the Chinese Building Industry: Drivers and Impediments. Journal of Technology Management in China. 7(1): 50-63. DOI: $10.1108 / 17468771211207349$. 